\title{
The fentanyl concentration required for immobility under propofol anesthesia is reduced by pre-treatment with flurbiprofen axetil
}

\section{La concentration de fentanyl nécessaire à l'immobilité au cours d'une anesthésie au propofol est diminuée par un prétraitement avec du flurbiprofène axétil}

\author{
Mitsuharu Kodaka, MD • Mikiko Tsukakoshi, MD · Hideki Miyao, MD • \\ Koichi Tsuzaki, MD · Junko Ichikawa, MD • Makiko Komori, MD \\ Received: 15 March 2013/Accepted: 20 September 2013/Published online: 27 September 2013 \\ (C) Canadian Anesthesiologists' Society 2013
}

\begin{abstract}
Purpose We hypothesized that nonsteroidal antiinflammatory drugs decrease the plasma fentanyl concentration required to produce immobility in $50 \%$ of patients in response to skin incision (Cp50 incision) compared with placebo under target-controlled infusion (TCI) propofol anesthesia.

Methods Sixty-two unpremedicated patients scheduled to undergo gynecologic laparoscopy were randomly assigned to receive placebo (control group) or flurbiprofen axetil $1 \mathrm{mg} \cdot \mathrm{kg}^{-1}$ (flurbiprofen group) preoperatively. General anesthesia was induced with fentanyl and propofol, and intubation was performed after succinylcholine $1 \mathrm{mg} \cdot \mathrm{kg}^{-1}$.
\end{abstract}

Author contributions Mitsuharu Kodaka, Mikiko Tsukakoshi, Hideki Miyao, and Koichi Tsuzaki were involved in the study design. Mitsuharu Kodaka and Hideki Miyao were involved in conducting the study. Mitsuharu Kodaka, Koichi Tsuzaki, Junko Ichikawa, and Makiko Komori were involved in the data analysis. Mitsuharu Kodaka, Mikiko Tsukakoshi, Hideki Miyao, Koichi Tsuzaki, Junko Ichikawa, and Makiko Komori were involved in writing the manuscript.

M. Kodaka, MD $(\bowtie) \cdot$ J. Ichikawa, MD · M. Komori, MD Department of Anesthesiology, School of Medicine, Tokyo Women's Medical University, Medical Center East 2-1-10

Nishi-Ogu, Arakawa-ku, Tokyo 116-8567, Japan

e-mail:kmkodaka@cb3.so-net.ne.jp

J. Ichikawa, MD

e-mail: htwfx872@yahoo.co.jp

M. Komori, MD

e-mail: komorim@nifty.com

M. Tsukakoshi, MD · H. Miyao, MD

Department of Anesthesiology, Saitama Medical Center,

Saitama Medical University, Saitama, Japan
Propofol was administered via a target-controlled infusion (TCI) system (Diprifusor ${ }^{T M}$ ) set at an effect-site concentration of $5 \mu \mathrm{g} \cdot \mathrm{mL}^{-1}$. Fentanyl was given by a TCI system using the STANPUMP software (Schafer model). The concentration for the first patient was set at $3 \mathrm{ng} \cdot \mathrm{mL}^{-1}$ and modified in each group according to the updown method. Skin incision was performed after more than ten minutes equilibration time. Serum fentanyl concentration, bispectral index (BIS), and hemodynamic parameters were measured two minutes before and after skin incision. The Cp50 incision of fentanyl was derived from the mean of the crossovers (i.e., the serum fentanyl concentrations of successive participants who responded and those who did not or vice versa).

Results Ten and 11 independent crossover pairs were collected in the control and flurbiprofen groups, respectively, representing 42 of 62 enrolled patients. The mean (SD) fentanyl Cp50 incision was less in the flurbiprofen group $\left[0.84(0.63) n g \cdot m L^{-1}\right]$ than in the control group [1.65 (1.15) $\left.n g \cdot m L^{-1}\right] ; P=0.007$; however, there were no

M. Tsukakoshi, MD

e-mail: mtsukakoshi@saitama-med.ac.jp

H. Miyao, MD

e-mail: miyaoh@saitama-med.ac.jp

K. Tsuzaki, MD

School of Medicine, Keio University, Keio, Japan

e-mail: ktsuzaki@sc.itc.keio.ac.jp 
differences in BIS, blood pressure, or heart rate, between groups.

Conclusion Preoperative flurbiprofen axetil decreased the Cp50 incision of fentanyl by $49 \%$ during propofol anesthesia without changing the BIS or hemodynamic variables.

\section{Résumé}

Objectif Nous avons émis l'hypothèse que des anti-inflammatoires non stérö̈diens diminuaient la concentration plasmatique de fentanyl nécessaire pour obtenir une immobilité chez $50 \%$ des patients en réponse à

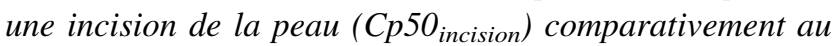
placebo au cours d'une anesthésie au propofol en perfusion avec objectif de concentration.

Méthodes Soixante-deux patientes non prémédiquées devant subir une laparoscopie gynécologique ont été randomisées pour recevoir un placebo (groupe témoin) ou du flurbiprofène axétil $1 \mathrm{mg} \cdot \mathrm{kg}^{-1}$ (groupe flurbiprofène) en préopératoire. L'anesthésie générale a été induite avec du fentanyl et du propofol et l'intubation a été réalisée après l'administration de 1 de succinylcholine $\mathrm{mg} \cdot \mathrm{kg}^{-1}$. Le propofol a été administré au moyen d'une perfusion à objectif de concentration (Diprifusor ${ }^{T M}$ ) réglé pour une concentration au site d'action de $5 \mu \mathrm{g} \cdot \mathrm{mL}^{-1}$. Le fentanyl a été administré au moyen d'un même système avec un modèle STANPUMP-Schafer; la concentration a été établie pour la première patiente à $3 \mathrm{ng} \cdot \mathrm{mL}^{-1}$ puis modifiée à la hausse ou à la baisse dans chaque groupe selon la réponse de la patiente précédente. L'incision de la peau a été réalisée après plus de dix minutes en phase d'équilibre. La concentration plasmatique de fentanyl, l'indice bispectral (BIS) et les paramètres hémodynamiques ont été mesurés deux minutes avant et deux minutes après l'incision de la peau. La Cp50 incision du fentanyl a été tirée de la moyenne des croisements (c'est-à-dire les concentrations sériques de fentanyl des participantes qui présentaient une réponse et celles des patientes qui ne présentaient pas de réponse ou vice versa).

Résultats Dix et onze paires indépendantes de croisements ont été collectées dans, respectivement, les groupes témoin et flurbiprofène, représentant 42 des 62 patientes incluses. La Cp50 incision du fentanyl a été plus basse dans le groupe flurbiprofène (moyenne [ET] : 0,84 [0,63] $\left.n g \cdot m L^{-1}\right)$ que dans le groupe témoin $\left(1,65[1,15] \mathrm{ng} \cdot \mathrm{mL} \mathrm{L}^{-1}\right)$; $P=0,007) ;$ cependant aucune différence entre les groupes n'a été retrouvée pour le BIS, la tension artérielle ou la fréquence cardiaque.

Conclusion L'administration préopératoire de flurbiprofène axétil a abaissé la $\mathrm{Cp}^{50_{\text {incision }}}$ du fentanyl de $49 \%$ au cours d'une anesthésie au propofol sans modification du BIS ou des variables hémodynamiques.
When patients are anesthetized with propofol and fentanyl without a neuromuscular blocking agent, there is a high incidence of movement in response to painful stimuli. ${ }^{1}$ Relatively high concentrations of fentanyl and/or propofol are usually required to abolish this response, possibly causing cardiovascular and respiratory depression. ${ }^{2}$ Nonsteroidal anti-inflammatory drugs (NSAIDs) alone are not considered to produce clinically relevant cardiovascular or respiratory depression, and these drugs are widely used to augment the analgesic effects of opioids, particularly in ambulatory surgery. ${ }^{3}$ We sought to describe and quantify the pharmacodynamic interaction between a NSAID, propofol, and fentanyl when administered simultaneously as part of a general anesthetic. In this study, we chose to use flurbiprofen axetil, a NSAID mainly used to control pain after ambulatory surgery. Flurbiprofen has been shown to decrease postoperative pain if given preoperatively to patients scheduled to undergo spinal fusion surgery. ${ }^{4}$

We conducted a randomized blinded controlled trial in which patients were administered flurbiprofen axetil $1 \mathrm{mg} \cdot \mathrm{kg}^{-1}$ or placebo. We hypothesized that administering flurbiprofen axetil before surgery would reduce the $\mathrm{Cp} 50_{\text {incision }}$ (the serum concentration needed to suppress the movement response to skin incision in $50 \%$ of patients) of fentanyl during pseudo-steady-state anesthesia when fentanyl and propofol were administered as targetcontrolled infusions (TCI). Secondary endpoints were the changes in bispectral index (BIS), heart rate (HR), and blood pressure (BP) after skin incision.

\section{Methods}

The study was approved by the Medical Ethics Committee of Saitama Medical Center/University (approval date Nov 29, 2005, reference number \#14-2; http://www.saitamamed.ac.jp/kawagoe/05others/chiken/LocalSite/smc_iec/070. iec_ver.1.0_090826.html) and performed from December 2005 to January 2007. After obtaining written informed consent, 62 females (American Society of Anesthesiologists physical status I-II; 20-55 yr of age) scheduled to undergo gynecologic laparoscopy were enrolled. Patients with hepatic or renal disease, those with a body mass index (BMI) $>$ $30 \mathrm{~kg} \cdot \mathrm{m}^{-2}$, or those taking long-term analgesics were excluded. Patients were recruited during preoperative assessment and treated by the same gynecologists. No preoperative sedation or analgesics were administered. Once the patient was in the operating room, routine monitoring of the electrocardiogram, pulse oximetry, noninvasive BP, BIS, and end-tidal $\mathrm{CO}_{2}$ (VL-910R; Nihon Kohden Corp., Tokyo, Japan) was established. A BIS monitor (BIS A2000, version 
3.2; Aspect Medical Systems, Natick, MA, USA) was connected to the patient's forehead (single channel: Fp1-Fpz). Bispectral index, raw electroencephalogram, hemodynamic variables, and end-tidal $\mathrm{CO}_{2}$ data were automatically exported to a computer at five-second intervals during the study.

The treatment assignments were contained in sequentially numbered opaque sealed envelopes. Fentanyl was administered as a computer-controlled infusion using a Graseby 3500 infusion pump driven by a laptop computer using STANPUMP software. ${ }^{5}$ The pharmacokinetic and pharmacodynamic parameters described by Shafer (http:// anesthesia.stanford.edu/pkpd/) were used in the effect-site mode with a target concentration chosen according to the modified up-and-down method. ${ }^{6,7}$ An investigator (M.K.) controlled this process and prepared all drug infusions. The fentanyl effect-site concentration was set at $3 \mathrm{ng} \cdot \mathrm{mL}^{-1}$ for the first patient. For all other patients, the target concentration was increased by $0.5 \mathrm{ng} \cdot \mathrm{mL}^{-1}$ if the previous patient had moved in response to skin incision, or decreased by $0.5 \mathrm{ng} \cdot \mathrm{mL}^{-1}$ if the previous patient had not moved. After a few minutes, we also started a propofol TCI incorporating the standard Diprifusor ${ }^{\mathrm{TM}}$ pharmacokinetic model ${ }^{8}$ developed by Gepts ${ }^{9}$ and Marsh ${ }^{10}$ using an anesthetic pump (TE371, Terumo, Japan) with a prefilled syringe (AstraZeneca, Osaka, Japan). The target plasma concentration of propofol was initially set at $6.0 \mu \mathrm{g} \cdot \mathrm{mL}^{-1}$. After achieving loss of consciousness and BIS $<60$, the patient's trachea was intubated after administering succinylcholine $1 \mathrm{mg} \cdot \mathrm{kg}^{-1}$. After intubation, a blinded investigator (K.T., M.T., and H.M.) administered either placebo or flurbiprofen axetil $1 \mathrm{mg} \cdot \mathrm{kg}^{-1}$ intravenously over one minute.

A radial arterial catheter $(22 \mathrm{G})$ was used for blood sampling. After the effect-site concentration of propofol reached $5.0 \mu \mathrm{g} \cdot \mathrm{mL}^{-1}$, the propofol plasma target concentration was decreased from 6.0 to $5.0 \mu \mathrm{g} \cdot \mathrm{mL}^{-1}$. After ten minutes to allow equilibrium to be reached between the predetermined blood and effect-site concentrations of fentanyl and propofol, we used a nerve stimulator to check that neuromuscular function had returned and then applied surgical stimulation.

\section{Surgical stimulation}

After an equilibration time of at least ten minutes, the surgeon applied three stimuli of increasing intensity: pinching with tweezers at the incision site; making a $15-20 \mathrm{~mm}$ skin incision; and inserting the trocar into the peritoneum. If a gross purposeful movement occurred as a response to any of these stimuli, succinylcholine $20 \mathrm{mg}$ was administered and the response was considered positive. After withdrawing blood samples, we administered fentanyl 50-100 $\mu \mathrm{g}$ to provide additional analgesia. Coughing, chewing, and/or swallowing were not considered a positive response.

After the incision, investigators (K.T., M.T., and H.M.) who were unaware of the patient's randomization status, evaluated movement for one minute. Blood samples were collected, and BIS and hemodynamic variables were recorded two minutes before and after incision. This concluded the protocol, and the subsequent conduct of anesthesia was left to the discretion of the anesthesiologist.

The $\mathrm{Cp} 50_{\text {incision }}$ was defined as the mean plasma concentration of independent crossover pairs within each group. A crossover represents a unique pair of sequential patients in which the first patient shows no incision-evoked movement at a given fentanyl target concentration while the next shows movement in response to $0.5 \mathrm{ng} \cdot \mathrm{mL}^{-1}$ less fentanyl (or vice versa).

\section{Fentanyl concentration assay}

All serum fentanyl assays were performed the day after the trial had been completed using high-performance liquid chromatography (HPLC) and a mass spectrometry system (MSMS). ${ }^{11}$ The techniques used to measure the fentanyl concentrations were as follows: The MSMS system was an LC/MS/MS system (API3000; Applied Biosystems/MDS Sciex, Tokyo, Japan). The HPLC system was an LC10ADvp system (Shimadzu Corp., Kyoto, Japan) connected to an analytical L-column (octadecyl silane, $5 \mu \mathrm{m} ; 2.1 \mathrm{~mm}$ inner diameter $\times 150 \mathrm{~mm}$; Chemical Evaluation and Research Institute, Tokyo, Japan). The standard deviation of the intra-day and inter-day limits was $\pm 15 \%$, and the dynamic range was $0.2 \sim 10 \mathrm{ng} \cdot \mathrm{mL}^{-1}$. The $\mathrm{Cp} 50_{\text {incision }}$ of fentanyl was calculated from the average of the plasma concentrations measured before and after skin incision. Therefore, the effect-site target concentration was used to determine the titration of fentanyl, but measured plasma concentration was used to determine the $\mathrm{Cp} 50_{\text {incision. }}$. The primary endpoint was plasma $\mathrm{Cp} 50_{\text {incision }}$ of fentanyl in the control and flurbiprofen groups and in responders and nonresponders. The secondary endpoints were differences in BIS, BP, and HR between the control and the flurbiprofen groups and between responders and non-responders under approximate steady-state conditions.

Statistical analysis

Student's $t$ test was used to determine the difference in measured and predicted concentration, total fentanyl dose, plasma fentanyl $\mathrm{Cp} 50_{\text {incision, }}$ and hemodynamic variables and to examine significant co-factors (age, weight, height, and BMI) between the two treatment groups using the JMP statistical software package (version 4.0.5 J, SAS Campus Drive, Cary, NC, USA). The average BIS was analyzed 
using the Mann-Whitney $\mathrm{U}$ test for non-parametric data. A two-sided $P$ value of $<0.05$ was considered statistically significant.

\section{Results}

The characteristics of all patients and those included in the crossover pairs are shown in Table 1; both groups were comparable. Fig. 1 shows the modified Dixon's up-down method based on the effect-site target fentanyl concentration predicted by the STANPUMP model. Sequential samples for each patient are shown in ten and 11 independent crossover pairs of patients enrolled in the control and flurbiprofen groups, respectively, representing 42 of 62 enrolled patients. Fig. 2 displays the measured plasma fentanyl concentrations and shows that steady state was achieved in the majority of patients. The mean (SD) times from intravenous flurbiprofen axetil or placebo administration to skin incision in the control and flurbiprofen groups were: 17.6 (9.3) min (range 12-30 min) vs 20.1 (7.0) min (range 13-39 min), respectively $(P=0.322)$. Furthermore, no significant differences were found between groups regarding BIS, HR, and BP measured before or after incision or expressed as percent changes (Tables 2 and 3).

The mean (SD) fentanyl $\mathrm{Cp} 50_{\text {incision }}$ derived from the mean values measured before and after incision in crossover pairs was significantly lower in the flurbiprofen group than in the control group $\left[0.84(0.63) \mathrm{ng} \cdot \mathrm{mL}^{-} 1\right.$ vs 1.65 (1.15) $\mathrm{ng} \cdot \mathrm{mL}^{-1}$, respectively; $P=0.007$ ] (Fig. 3). There were no statistically significant mean (SD) differences between the measured plasma concentration of fentanyl and the setting for the target fentanyl concentration on the STANPUMP

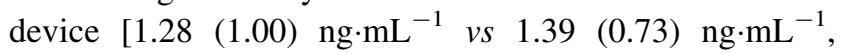
respectively; $P=0.546$ ]. Fig. 4 and Table 4 show the measured plasma fentanyl concentrations, hemodynamics, and BIS of the responders and non-responders before and after incision. The mean (SD) plasma fentanyl concentration (before and after incision) of responders was significantly

Table 1 Patient characteristics of whole study patients (left) and crossover pairs alone (right) expressed as mean (standard deviation)

\begin{tabular}{lrllrr}
\hline Group & \multicolumn{2}{l}{ All patients } & & \multicolumn{2}{l}{$\begin{array}{l}\text { Patients included in } \\
\text { crossover analysis }\end{array}$} \\
\cline { 2 - 3 } \cline { 5 - 6 } \cline { 5 - 6 } & $\begin{array}{l}\text { Control } \\
(n=31)\end{array}$ & $\begin{array}{l}\text { Flurbiprofen } \\
(n=31)\end{array}$ & $\begin{array}{l}\text { Control } \\
(n=20)\end{array}$ & $\begin{array}{l}\text { Flurbiprofen } \\
(n=22)\end{array}$ \\
\hline Age; yr & $34.7(4.9)$ & $35.6(7.2)$ & & $34.0(4.0)$ & $35.1(7.0)$ \\
Height; cm & $160.5(5.2)$ & $157.2(5.6)$ & & $161.7(5.4)$ & $157.1(5.4)$ \\
Weight; kg & $54.6(8.3)$ & $52.2(7.1)$ & & $55.7(8.9)$ & $51.7(5.6)$ \\
BMI; $\mathrm{kg} \cdot \mathrm{m}^{-2}$ & $21.2(3.3)$ & $21.1(2.6)$ & $21.4(3.5)$ & $21.0(2.3)$ \\
\hline
\end{tabular}

$\mathrm{BMI}=$ body mass index lower than that of non-responders $\left[0.92(0.74) \mathrm{ng} \cdot \mathrm{mL}^{-1} v s\right.$ $\left.1.64(1.11) \mathrm{ng} \cdot \mathrm{mL}^{-1} ; P=0.018\right]$. Before incision, BP, BIS, and HR were all significantly lower in non-responders than responders; however, after incision, only HR was significantly lower (Table 4). No patient experienced any complications, such as critical hypotension, bradycardia, awareness during surgery, or clinically relevant perioperative bleeding.

\section{Discussion}

Pre-surgical administration of flurbiprofen axetil $\left(1 \mathrm{mg} \cdot \mathrm{kg}^{-1}\right)$ decreased the $\mathrm{Cp} 50_{\text {incision }}$ of fentanyl by $49 \%$ under $5 \mu \mathrm{g} \cdot \mathrm{mL}^{-1}$ propofol TCI anesthesia without changing BIS or hemodynamic variables. The mean plasma fentanyl concentrations and the before and after-incision fentanyl concentrations of non-responders were significantly higher than those of responders. The hemodynamic parameters and BIS of non-responders before incision were significantly lower than those of responders, but only HR was significantly lower after the incision. Thus, an NSAID administered before surgery can decrease the dose of opioid required to provide sufficient analgesia (manifest in this study by lack of movement) for a skin incision under propofol TCI anesthesia. Our findings show that, in the absence of a neuromuscular blocking agent, a preoperative dose of the NSAID, flurbiprofen, reduces the dose of opioid required to prevent movement in response to a surgical stimulus without influencing the hemodynamic or BIS responses.

Cyclo-oxygenase (COX) inhibitors are known to be effective in suppressing central nervous system activity, as demonstrated in the thermal hyperalgesia ${ }^{12}$ and formalininduced pain models in rats. ${ }^{13}$ Despite being effective analgesics, opioids have several adverse side effects, including acute respiratory and hemodynamic suppression, postoperative nausea and vomiting, rigidity, urinary retention, and cough. We tested whether coadministration of a NSAID with the synthetic opioid, fentanyl, could decrease the opioid concentration necessary for effectively inhibiting movement caused by a skin incision and thus potentially decrease the incidence of opioid-induced side effects and complications.

A critical issue for the feasibility of this study design was the choice of the optimal initial concentrations of propofol and fentany. ${ }^{1}$ Other investigators have determined the $\mathrm{Cp} 50_{\text {incision }}$ of propofol and fentanyl, albeit under different circumstances. Smith et al. ${ }^{1}$ reported that the $\mathrm{Cp} 50_{\text {incision }}$ of fentanyl was $1.0 \mathrm{ng} \cdot \mathrm{mL}^{-1}$ when the propofol concentration was $4.0 \mu \mathrm{g} \cdot \mathrm{mL}^{-1}$. Since we often observed movement at incision at these concentrations, we decided to use higher concentrations to reduce discomfort, 


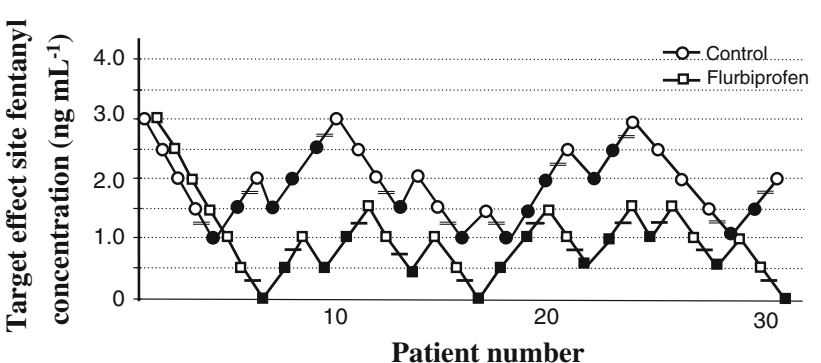

Fig. 1 The modified Dixon's up-and-down method. The $x$-axis shows consecutive patient numbers and the $y$-axis shows the predicted (target) effect-site fentanyl concentration. The circles and squares represent the control and flurbiprofen, respectively. Open circles and squares $(\bigcirc, \square)$ represent non-responders, and the closed symbols $(\boldsymbol{}$, - represent responders. The crossbars represent crossover midpoint for control (double horizontal bar) and flurbiprofen (thick horizontal $\underline{\text { bar) }}$

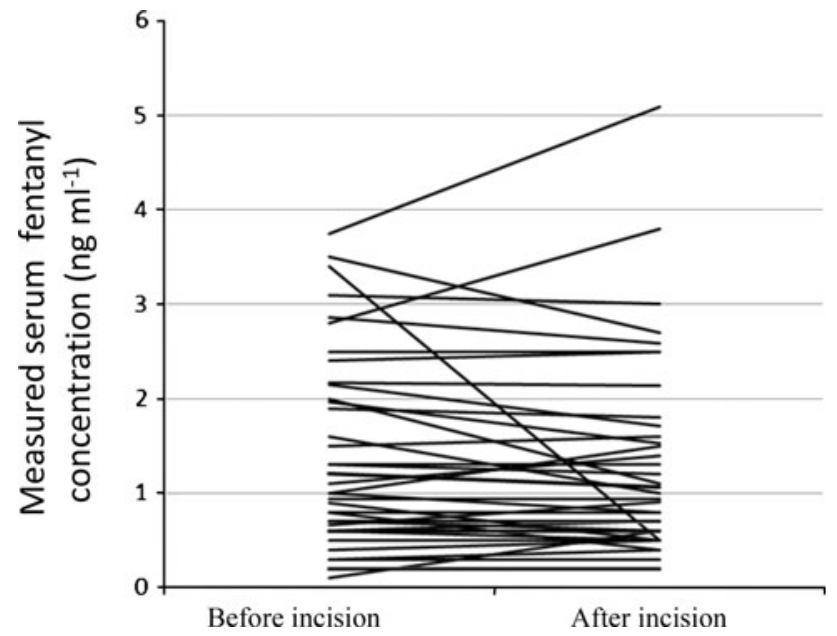

Fig. 2 Sequential measured plasma fentanyl concentrations of each participant before and after skin incision. The mean (SD) values were $1.32(1.02) \mathrm{ng} \cdot \mathrm{mL}^{-1}$ and $1.23(1.06) \mathrm{ng} \cdot \mathrm{mL}^{-1}$, respectively $(n=42)$; $P=0.704$ analyzed by Student $t$ test

reduce the risk of awareness, and reflect our clinical practice more closely. In contrast, Kazama et al. ${ }^{14}$ found that the $\mathrm{Cp} 50_{\text {incision }}$ of fentanyl was $3 \mathrm{ng} \cdot \mathrm{mL}^{-1}$, a value twofold higher than that identified in our study. Several reasons may account for these differences: the use of a smaller skin incision; stimulation of the peritoneum using a laparoscopic trocar; differences in the TCI algorithms, or an extremely homogenous group of patients.

Several previous studies have examined the interactions between opioids and NSAIDs during surgery; however, in these studies, most NSAIDs were administered orally or rectally and the resultant slow absorption made it difficult to show the efficacy of NSAIDs in inhibiting movement during skin incision. Several studies have examined the interaction of NSAIDs and opioids in rodent pain models.
Table 2 Bispectral index (BIS) and hemodynamic variables before and after incision. Values are mean (standard deviation) or median [interquartile range] (range)

\begin{tabular}{|c|c|c|c|c|}
\hline & & Control & Flurbiprofen & $P$ value \\
\hline \multirow[t]{4}{*}{$\begin{array}{l}\text { Before } \\
\quad \text { incision }\end{array}$} & BIS & $\begin{array}{c}31.5[25-39] \\
\quad(23-55)\end{array}$ & $\begin{array}{c}31.5[25-41] \\
\quad(22-70)\end{array}$ & 0.791 \\
\hline & $\begin{array}{l}\text { Systolic BP } \\
(\mathrm{mmHg})\end{array}$ & $120.0(4.7)$ & $116.5(4.5)$ & 0.590 \\
\hline & $\begin{array}{l}\text { Diastolic BP } \\
(\mathrm{mmHg})\end{array}$ & $73.1(13.5)$ & $73.6(17.3)$ & 0.912 \\
\hline & $\begin{array}{l}\text { Heart rate } \\
\quad\left(\text { beats } \cdot \min ^{-1} \text { ) }\right.\end{array}$ & $70.0(11.2)$ & $73.5(12.1)$ & 0.132 \\
\hline \multirow[t]{4}{*}{$\begin{array}{l}\text { After } \\
\quad \text { incision }\end{array}$} & BIS & $\begin{array}{l}29.0[27-41] \\
\quad(22-48)\end{array}$ & $\begin{array}{c}32.5[28-39] \\
(24-48)\end{array}$ & 0.752 \\
\hline & $\begin{array}{l}\text { Systolic BP } \\
\text { (mmHg) }\end{array}$ & $126.9(4.4)$ & $124.7(4.2)$ & 0.724 \\
\hline & $\begin{array}{l}\text { Diastolic BP } \\
\quad(\mathrm{mmHg})\end{array}$ & $81.4(12.4)$ & $83.1(14.9)$ & 0.666 \\
\hline & $\begin{array}{l}\text { Heart rate } \\
\quad\left(\text { beats } \cdot \min ^{-1}\right)\end{array}$ & $69.1(9.8)$ & $73.9(16.0)$ & 0.252 \\
\hline
\end{tabular}

$\mathrm{BP}=$ blood pressure

Table 3 Percent changes in BIS and hemodynamics (after valuesbefore values/before values). Values are mean (standard deviation). There was no significant difference between the groups

\begin{tabular}{lclc}
\hline Group & Control & $\begin{array}{l}\text { Flurbiprofen } \\
\text { group }\end{array}$ & $P$ value \\
\hline $\begin{array}{l}\text { \%Change of BIS } \\
\begin{array}{l}\text { \% Change of systolic BP } \\
(\mathrm{mmHg})\end{array}\end{array}$ & $0.4(15.5)$ & $2.5(15.8)$ & 0.55 \\
$\begin{array}{l}\text { \% Change of diastolic BP } \\
\text { (mmHg) }\end{array}$ & $13.3(8.3)$ & $15.6(21.2)$ & 0.71 \\
$\begin{array}{l}\text { \% Change of heart rate } \\
\text { (beats.min }\end{array}$ & $2.3(11.7)$ & $2.2(15.8)$ & 0.31 \\
\hline
\end{tabular}

$\mathrm{BIS}=$ bispectral index $; \mathrm{BP}=$ blood pressure

Santos et al. ${ }^{15}$ reported that acetylsalicylic acid, but not the more selective COX-2 isoform inhibitor, meloxicam, could further reduce the minimum alveolar concentration of isoflurane in rats when combined with morphine, suggesting that selective COX-1 isoform inhibition may be necessary to enhance the effects of opioids. Kolesnikov et al. ${ }^{16}$ reported a synergistic interaction between ibuprofen (predominantly a COX-1 inhibitor) and hydrocodone (a $\mu$ opioid receptor agonist) in the murine non-inflammatory radiant heat tail-flick nociception model. Fletcher et al. ${ }^{17}$ also found a synergistic relationship between morphine and diclofenac in rats injected with carrageenan in an acute inflammatory pain model; however, a NSAID did not augment the analgesic effect of an opioid in a thermal nociception model in nerve-injured rats. ${ }^{18}$ Vaughan $^{19}$ and Williams et $a l .^{20}$ further investigated the mechanism of 


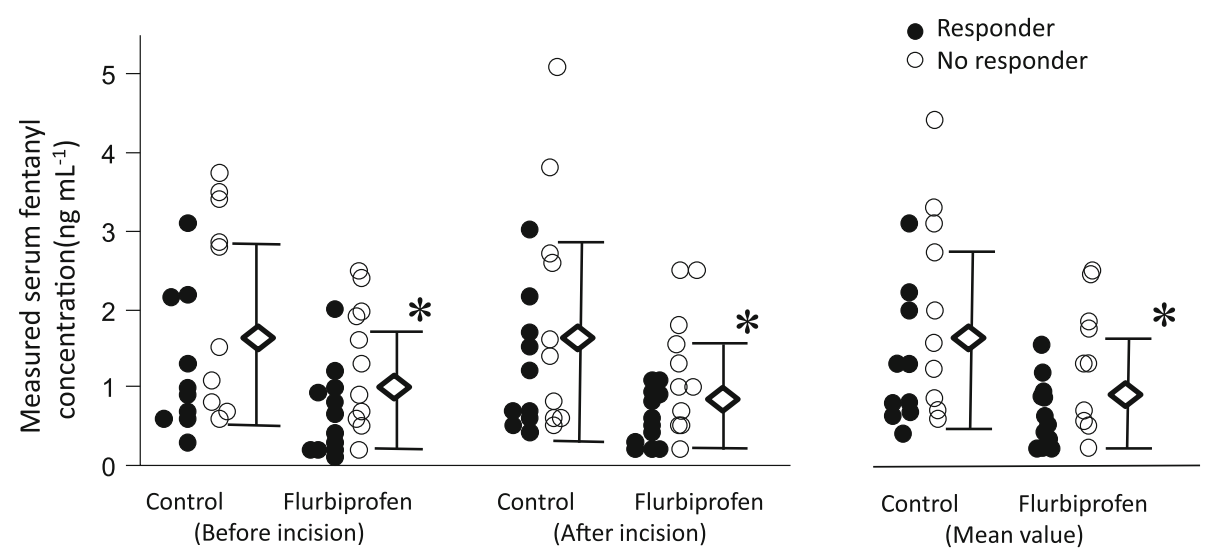

Fig. 3 The $\mathrm{Cp} 50_{\text {incision }}$ of fentanyl before and after skin incision in the flurbiprofen and placebo groups calculated from the values of 42 patients using the modified Dixon's up-and-down method. The open and closed circles indicate patients who did not respond and those

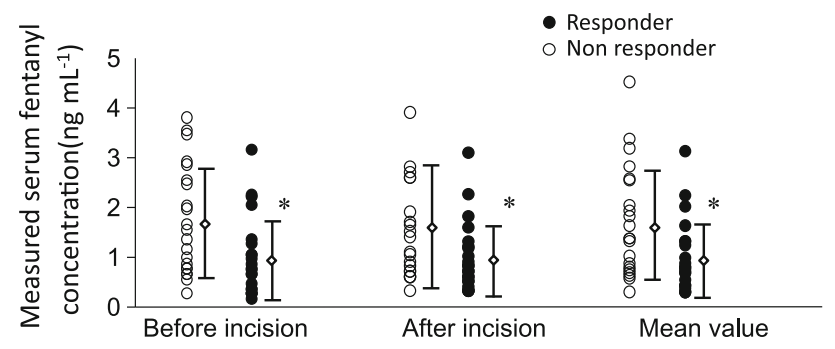

Fig. 4 Measured plasma fentanyl concentrations in responders $(n=21)$ and non-responders $(n=21)$, before incision, after incision and mean before and after values. The open and closed circles indicate patients who did not respond and those who responded, respectively. Data are expressed as mean (standard deviation) using squares and error bars of crossover pairs. $* P<0.05$ compared with patients who did not respond

these interactions. Opioids generally act on $\mu$-receptors in the paracerebral aqueduct of Sylvius. Binding of opioids to $\mu$-receptors inhibits the presynaptic release of $\gamma$ aminobutyric acid (GABA) through 5-lipoxygenase, while COX-1 inhibitors enhance the ability of 5-lipoxygenase to inhibit the release of GABA. It is believed that this synergistic action on GABA release may lead to enhanced analgesia. These findings also suggest that a more selective COX-1 inhibitor can further enhance the analgesic actions of opioids. Flurbiprofen axetil is a mixed COX inhibitor with a COX-1/COX-2 inhibitory ratio approximately $10 \%$ that of acetylsalicylic acid. ${ }^{21}$ We used flurbiprofen axetil in this study because it was the only injectable NSAID approved for use in Japan at the time.

Our study had several limitations. First, all patients were relatively lean middle-aged females and, as such, comprised a somewhat homogenous group, but even so, fentanyl concentrations were highly variable (Fig. 2). Sensitivity to who responded, respectively. Data are expressed as mean (standard deviation) using squares and error bars of crossover pairs. $* P<0.05$ compared with the control group

Table 4 Systolic blood pressure, diastolic blood pressure, heart rate, and BIS of responders (mover) and non-responders (non-mover)

\begin{tabular}{|c|c|c|c|c|}
\hline & & Responders & $\begin{array}{l}\text { Non- } \\
\text { responders }\end{array}$ & $P$ value \\
\hline \multirow{4}{*}{$\begin{array}{l}\text { Before } \\
\quad \text { incision }\end{array}$} & BIS & $38.1(12.9)$ & $30.8(8.1)$ & 0.035 \\
\hline & $\begin{array}{c}\text { Systolic BP } \\
(\mathrm{mmHg})\end{array}$ & $124.9(24.5)$ & 110.9 (13.7) & 0.03 \\
\hline & $\begin{array}{l}\text { Diastolic BP } \\
\quad(\mathrm{mmHg})\end{array}$ & $78.9(16.8)$ & $68.0(12.3)$ & 0.022 \\
\hline & $\begin{array}{l}\text { Heart rate } \\
\quad\left(\text { beats } \cdot \min ^{-1}\right)\end{array}$ & $75.2(12.6)$ & $66.0(9.1)$ & 0.001 \\
\hline \multirow{4}{*}{$\begin{array}{l}\text { After } \\
\quad \text { incision }\end{array}$} & BIS & $34.3(8.4)$ & $31.8(6.5)$ & 0.287 \\
\hline & $\begin{array}{c}\text { Systolic BP } \\
(\mathrm{mmHg})\end{array}$ & $129.6(20.3)$ & $122.3(16.9)$ & 0.216 \\
\hline & $\begin{array}{l}\text { Diastolic BP } \\
\quad(\mathrm{mmHg})\end{array}$ & 83.7 (14.9) & $81.2(11.8)$ & 0.555 \\
\hline & $\begin{array}{l}\text { Heart rate } \\
\quad\left(\text { beats } \cdot \min ^{-1}\right)\end{array}$ & $76.5(14.5)$ & $67.3(9.5)$ & 0.022 \\
\hline
\end{tabular}

Values are mean (standard deviation). BIS = bispectral index; $\mathrm{BP}=$ blood pressure; $\mathrm{HR}=$ heart rate

intravenous anesthesia reportedly differs between sexes, ${ }^{7,22}$ therefore, our results may not be applicable to males, children, the elderly, or the obese. Second, we used a modified version of Dixon's up-and-down method which can be used for only a narrower range of concentrations and only to identify Cp50 and not Cp95. Third, the painful stimuli comprised pinching, making a skin incision, and inserting the trocar into the peritoneum. Higher initial doses were required in this study compared with those used in other propofol-fentanyl studies, likely reflecting differences in the intensity of pain caused by the initial incision and trocar placement. Moreover, these results may be valid only for 
propofol effect-site concentrations of approximately $5 \mu \mathrm{g} \cdot \mathrm{mL}^{-1}$, somewhat higher concentrations than usual, and even small inaccuracies in the estimated propofol concentration (in the context of an expected prediction error of at least 20\%) may influence the determination of the $\mathrm{Cp} 50_{\text {incision }}$ of fentanyl. If we had chosen a lower target concentration of propofol, we would have needed more fentanyl to abolish movement, so the effect of the same dose of flurbiprofen would likely have been diminished. Conversely, if we had chosen a higher propofol concentration, the serum fentanyl concentration required to abolish movement may have been lower, raising the possibility that flurbiprofen alone might have been sufficient to abolish movement, thus effectively decreasing fentanyl requirements by $100 \%$. It is likely that the magnitude of the effect depends greatly on the balance between the plasma concentrations of propofol and fentanyl.

Although the plasma propofol concentrations used for analysis in this study were predicted values, Marsh et al. ${ }^{10}$ showed that the correlation between measured and predicted values was adequate for clinical use. Nevertheless, the predicted value of the Diprifusor tends to underestimate the measured concentration, particularly shortly after induction. The accuracy (median performance error; MDPE) and precision (median absolute performance error; MDAPE) are $16.2 \%$ and $24.1 \%$, respectively. ${ }^{8}$ Although effect-site concentrations could not be obtained, BIS provided a dynamic measure of anesthetic effect. Furthermore, although there was no difference between groups in the time to administration of flurbiprofen or placebo, there is no guarantee that the intensity of the effects of flurbiprofen was the same in all subjects at the time of skin incision.

\section{Conclusions}

Pre-administration of flurbiprofen axetil $1 \mathrm{mg} \cdot \mathrm{kg}^{-1}$ decreased the $\mathrm{Cp} 50_{\text {incision }}$ of fentanyl by $49 \%$ under $5 \mu \mathrm{g} \cdot \mathrm{mL}^{-1}$ propofol TCI anesthesia. Preoperative administration of flurbiprofen axetil appears to be an effective means of decreasing the dose of fentanyl required to prevent movement during skin incision in females undergoing gynecological laparoscopy. Furthermore, this practice does not perturb BIS, BP or HR. A reduced perioperative dose of fentanyl may consequently reduce the incidence of opioid-induced side effects, such as postoperative pain and postoperative nausea and vomiting, a hypothesis that requires further study.

Acknowledgments The study was approved by the Medical Ethics Committee (date Nov 29, 2005, reference \#14-2) of Saitama Medical Center / University. Website and address: http://www.saitama-med.
ac.jp/kawagoe/05others/chiken/LocalSite/smc_iec/070._iec_ver.1.0_ 090826.html and 1981 Tsujido-cho, Kamoda, Kawagoe, Saitama 350-8550, Japan. Telephone +81-48-228-3400.

Financial support None.

Competing interests The authors have no conflicts of interest to declare.

\section{References}

1. Smith C, McEwan AI, Jhaveri R, et al. The interaction of fentanyl on the Cp50 of propofol for loss of consciousness and skin incision. Anesthesiology 1994; 81: 820-8.

2. Robinson BJ, Ebert TJ, O'Brien TJ, Colinco MD, Muzi M. Mechanisms whereby propofol mediates peripheral vasodilation in humans. Sympathoinhibition or direct vascular relaxation? Anesthesiology 1997; 86: 64-72.

3. White FP. The role of non-opioid analgesic techniques in the management of pain after ambulatory surgery. Anesth Analg 2002; 94: 577-85.

4. Yamashita K, Fukusaki $M$, Ando $Y$, et al. Preoperative administration of intravenous flurbiprofen axetil reduces postoperative pain for spinal fusion surgery. J Anesth 2006; 20: 92-5.

5. Shafer SL, Varvel JR, Aziz, N, Scott JC. Pharmacokinetics of fentanyl administration by computer-controlled infusion pump. Anesthesiology 1990; 73: 1091-102.

6. Kodaka M, Johansen JW, Sebel PS. The influence of gender on loss of consciousness with sevoflurane or propofol. Anesth Analg 2005; 101: 377-81.

7. Dixon WJ. Staircase bioassay: the up-and-down method. Neurosci Biobehav Rev 1991; 15: 47-50.

8. Swinhoe CF, Peacok JE, Glen JB, Reilly CS. Evaluation of the predictive performance of a 'Diprifusor'TCI system. Anaesthesia 1998; 53(Suppl 1): 61-7.

9. Gepts E, Camu F, Cockshott ID, Douglas EJ. Disposition of propofol administered as constant rate intravenous infusion in humans. Anesth Analg 1987; 66: 1256-63.

10. Marsh B, White M, Morton N, Kenny GN. Pharmacokinetic model driven infusion of propofol in children. Br J Anaesth 1991; 67: 41-8.

11. Plummer GF. Improved method for the determination of propofol in blood by high performance liquid chromatography with fluorescence detection. J Chromatogr 1987; 421: 171-6.

12. Dirig DM, Isakson PC, Yaksh TL. Effect of COX-1and COX-2 inhibition on induction and maintenance of carrageenan-evoked thermal hyperalgesia in rats. J Pharmacol Exp Ther 1998; 285: 1031-8.

13. Dirig DM, Konin GP, Isakson PC, Yaksh TL. Effect of spinal cyclooxygenase inhibitors in rats using the formalin test and in vitro prostaglandin E2 release. Eur J Pharmacol 1997; 331: 155-60.

14. Kazama T, Ikeda K, Morita $K$. Reduction by fentanyl of the Cp50 values of propofol and hemodynamic response to various noxious stimuli. Anesthesiology 1997; 87: 213-27.

15. Santos $M$, Kunkar $V$, Garcia-Iturralde $P$, Tendillo FJ. Meloxicam, a specific COX-2, does not enhance the isoflurane minimum alveolar concentration reduction produced by morphine in the rat. Anesth Analg 2004; 98: 359-63.

16. Kolesnikov YA, Wilson RS, Pasternak GW. The synergistic analgesic interactions between hydrocodone and ibuprofen. Anesth Analg 2003; 97: 1721-3. 
17. Fletcher D, Benoist JM, Gautron M, Guilbaud G. Isobolographic analysis of interactions between intravenous morphine, propacetamol, and diclofenac in carrageenin-injected rats. Anesthesiology 1997; 87: 317-26.

18. Lashbrook JM, Ossipov MH, Hunter JC, Raffa RB, Tallarida RJ, Porreca F. Synergistic antiallodynic effects of spinal morphine with ketorolac and selective COX1- and COX2-inhibitors in nerve-injured rats. Pain 1999; 82: 65-72.

19. Vaughan CW, Ingram SL, Connor MA, Christie MJ. How opioids inhibit GABA-mediated neurotransmission. Nature 1997; 390: 611-4.
20. Williams JT. The painless synergism of aspirin and opium. Nature 1997; 390: 557-9.

21. Izeki M. Flurbiprofen axetil. Pain Clinic (Japanese) 2005; 26: S225-32.

22. Kodaka M, Suzuki T, Maeyama A, Koyama K, Miyao H. Gender differences between predicted and measured propofol CP50 for loss of consciousness. J Clin Anesth 2006; 18: 486-9. 